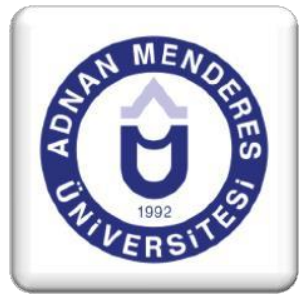

\section{Küresel Kamusal Mallar Yaklaşımıyla \\ Karayolu Trafik Güvenliğine Yönelik}

Hizmetler

Akif ŞARE ${ }^{1}$, Recep TEKELI $^{2}$

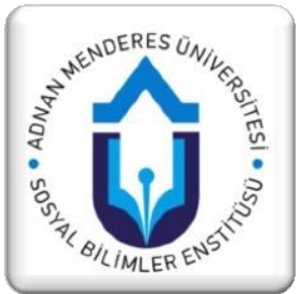

\title{
ÖZET
}

Karayollarında güvenli bir trafik akışı dünyadaki tüm devletler, sivil toplum örgütleri ve kişilerce istenir. Bu amaçla alınan önlemlere rağmen yol çarpışmaları büyük çapta yaşanan can kayıpları ve maddi hasarlara sebeptir.Toplumların kalkınmışlık düzeylerinin düşmesi, piyasa rekabetinde geri kalmaları ya da vasıflı işgücünün kaybı gibi ekonomik sorunlar yanında, sosyal hayatta da büyük problemlerin kaynağı olan karayolu trafik güvenliğine yönelik hizmetlerin yetersizliği, küreselleşmenin etkilerinin artmasıyla daha büyük bir sorun olarak karşımıza çıkmaktadır.Bu çalışma ile Karayolu Trafik Güvenliğinin artırılmasına dönük çabaların desteklenmesi amaçlanmaktadır. Kamusal mal tanımına göre daha kapsayıcı bakış açısıyla Küresel Kamusal Malların genel sınıflaması yapıldıktan sonra, çözüm için Karayolu Trafik Güvenliği ile Küresel Kamusal Mallar arasındaki ilişkiler incelenerek çalışma sonuçlandırılacaktır.

Anahtar Kelimeler: Küresel Kamusal Mallar, Trafik Güvenliği

\section{Road Safety Services In Terms of Global Public Goods}

\begin{abstract}
A safer traffic flow on the highways is desirable for all states, NGOs and people in the world. However, despite the precautions taken for this purpose, road collisions are still a major cause of life damages and material damage. The inadequacy of services for road traffic safety, which is a source of major problems in social life as well as economic problems such as declining societal development levels, lagging behind in market competition or lack of skilled labor, is becoming a bigger problem as the effects of globalization increase. This study aims to support global efforts to increase Road Traffic Safety. After a general classification of Global Public Goods is made from a more comprehensive view according to the definition of public goods, the study will be concluded by examining the relationship between Road Traffic Safety and Global Public Goods.
\end{abstract}

Keywords: Global Public Goods, Road Safety

\footnotetext{
${ }^{1}$ Şare Akif; Adnan Menderes Üniversitesi Nazilli İ̈BF İsabeyli Kampüsü, Nazilli /AYDIN. E-mail: akifsare@gmail.com.( Adnan Menderes Üniversitesi BAP tarafindan desteklenmiştir.)

${ }^{2}$ Tekeli Recep; Adnan Menderes Üniversitesi, Aydın İktisat Fakültesi AYDIN. E-mail: rtekeli@adu.edu.tr
} 


\section{Kamusal Mal Kavramına Yeni Bir Bakıș; Küresel Kamusal Mallar}

Küreselleşme eğilimlerinin oluşturduğu değişim süreciyle birlikte, geleneksel anlamda daha kapalı ve devletçi bir yapı içerisinde sunulan kamusal mallar, günümüzde daha kapsayıcı ve geniş çerçeveli olarak sunulmaktadır. Böylelikle kamu ve özel kesim arasında sınırlar daha geçirgen hale gelmekte, kamusal mal sunumu açısından yerel ve uluslar arası işbirliğinin önemi de artmaktadır (Kaul \& Conceiçao, 2006a: 4).

Bu noktada küresel boyutta artan sorunların çözümü adına, kamusal bir dışlanamazlıktan gelen kapsayıcılık özelliği önemle üstünde durulması gereken bir noktadır. Bu açıdan artık, tüm insanları, tüm nüfus ve gelir gruplarını kapsayan mallar kamusal mallar olarak tanımlanmaktadır (Kaul, 1999: 12).

Bilgi ve bilişim teknolojilerinin yaygınlaşmasıyla, kamusal malların sunumu sırasında kapsayıcılık özelliği yanında, sunumun adaletli ve şeffaf olarak yapılması da önem arz eden noktalar haline gelmiştir. Fakat kamusal mal ve hizmetlerin sunumu sırasında çok adil ve şeffaf bir yaklaşım içinde olunduğunda bile, kişilerin bu mal ve hizmetlere ulaşımı yine de bazı kişisel faktörlerin etkisiyle sınırlıdır. Örneğin elektriğin, bilgisayarın ve internetin var olduğu her toplumda, her bireyin bu hizmetlerden tam manasıyla yararlanması mümkündür denilemez. Kişisel tercihler, bireysel anlamda etkin rol oynamaktadır. Buradan hareketle kamusal mal ve hizmetlerin sunumu kadar tüketilmesi esnasinda da sosyal anlamda dışsallıklar oluşmaktadır.

İki kutuplu ve soğuk savaşın etkisi altında kalan bir dünyanın sona ermesi dünyadaki tüm sorunları, savaşları ve yoksulluğu önleyememiştir. Günümüzde hala dünya üzerinde gelir adaletli dağılmamakta, bazı insanlar günde 1 dolar sınırının altında kalan gelirleri ile yaşam mücadelesi vermekteler (Kaul, 2005: 3). Günümüzün küresel sorunları tek bir toplumsal kesim ya da katmanı dikkate alan sığ yaklaşımlarla aşılamayacak boyuttadır. Bu yüzden sorun odaklı ve çok disiplinli yaklaşımlar çözüm için önemlidir (Kaul, Grunberg, \& Stern, 1999a: xxiv).

Küresel bütünleşme ile birlikte ulus devletlerin yönetim kapasiteleri azalmış, küresel boyutta yaşanan sorunlara ve krizlere karşı ulusal devletlerin makroekonomik politika ve mali disiplin etkinliği giderek azalmıştır (Rao, 1999: 69). Bunun temelinde yatan sebeplerin başında, piyasa liberalizasyonu ve özelleştirmeler ile sermayenin artan hareketliliği gelmektedir (Rao, 1999: 68). Negatif dışsallıkların sınırları aşarak bölgesel ve küresel boyutta daha önemli sorunlara yol açması, ulus devletlerin devasa sorunlara tek başlarına çözüm üretememeleri gibi bir sonuçla karşı karşıya kalmalarına neden olmuştur. İşte tam bu noktada kamusal mallar, ulusal sınırlarından sıyrılarak küresel ve bölgesel bir nitelik kazanmışlardır (Çelebi \& Yalçın, 2008).

Kapsayıc1, adaletli ve şeffaf bir şekilde kamusal mal sunumunun gerçekleşmesi açısından, paydaşların sürece katılımı ve işbirliğinin öneminin her geçen gün arttığını söylememiz mümkündür. Bu sebeple, kamusal mallar kavramı geleneksel anlayıştan daha farklı bir anlam kazanmıştır. 'Küresel Kamusal Mallar' kavramı da bu süreçte, adil ve etkin kaynak kullanımı ya da aksi durumda oluşan olumsuzlukların önlenmesi amacıyla ortaya konan bir çözüm arayışının sonucudur. 'Küresel Kamusal Mallar' kavramı ilk kez 1999 yılında Birleşmiş Milletler Kalkınma Programı (UNDP) tarafından hazırlanan 'Global Public Goods' adlı çalışma ile kapsamlı bir şekilde gündeme gelmiştir. 
Küresel kamusal malları tanımlarken kimileri küresellik boyutunu ön plana çıkartmakta kimileri de kamusallık boyutunu daha çok önemsemektedir (Kirmanoğlu, Yılmaz, \& Susam, 2006: 26). Thoyer'in (2006) tanımlamasına göre küresel kamusal mallar; diğer ülkelerdeki nüfusun refahı için sonuçlara sahip olabilecek ve sadece bazı ülkelerin işbirliği, koordinasyon faaliyetleri ile üretilebilen, küresel refaha katk1 yapan malların seçimi ve üretimi olarak kabul edilmiştir. (Akdemir \& Şahin, 2006: 3)

Küresel kamusal malları konu eden çalışmalarda dikkati çeken önemli noktaları toparlayacak en genel tanım; Küresel Kamusal Mallar'ın tüketimi esnasında rekabetin olmaması ve dışlanamazlık özelliği barındırması yanında, fayda ya da zararların tüm dünya ülkelerine yay1lmas1, hatta nesiller boyu etkilerinin devam etmesidir (Kaul, Grunberg, \& Stern, 1999a: 17). Bunun yanında Dünya Bankası'nın vurguladığı bir diğer nokta da küresel kamusal malların çekirdek mallar ve tamamlayıcı mallar şeklinde ayrıma tabi tutulmasıdır (Kirmanoğlu, Yılmaz, \& Susam, 2006: 29). Dünya Bankası'nın yaptı̆̆ı bu sınıflandırmaya göre küresel kamusal mallar tüm ülkelere eşit olarak dağılsa bile, faydalarının ortaya çıkması için ilgili ülkelerde bazı temel alt yapı hizmetlerinin mevcut olması gerekir ki, bu da kalkınma ile ilgili bir meseledir (Kirmanoğlu, Yılmaz, \& Susam, 2006: 30).

\section{Küresel Kamusal Malların Sunumunun Önemi}

Geleneksel olarak kamusal malların ulusal düzeyde ele alınması yaklaşımı yakın geçmişe kadar belirgin bir özellik olarak karşımıza çıkmaktadır. Bu anlayışın temel söylemi, devletin piyasa başarısızlıkları nedeniyle kamusal harcamalar yaparak (kamusal mal sunumu yaparak) piyasa etkinliğini sağlamaktadır, şeklindedir. Politik karar alma sürecinde etkin sunum yapılması piyasa mekanizmasında olduğu gibi, taleplerin açıklanması ile değil, merkezi ya da yerel idarenin talepleri biliyor olması yani siyasal mekanizmanın işlemesi ile sağlanır. Bunların finansmanı da çoğu zaman faydalanma ilkesine göre değil, ödeme gücü ilkesine göre gerçekleştirilir (Kirmanoğlu, Yılmaz, \& Susam, 2006: 27).

Oysa bugünlerde daha farklı bir anlayış kabul görmekte; buna göre toplumlar için iki önemli araç olan piyasa mekanizması ve politik (kamusal) karar alma süreci (hükümetler) güçlü ve zayıf yönleriyle irdelenerek işbirliği içinde olmalılar. Kısaca piyasalar ve devletlerin bir 'inter-aktif ortaklık' içerisinde olması gereklidir (Kaul \& Conceiçao, 2006a: 21). Çünkü küresel kamusal malların çok azı için, faydaların ya da zararların dağılımında tam veya tama yakın bir kamusallıktan söz edilebilir (Kirmanoğlu, Yılmaz, \& Susam, 2006: 27). Ayrıca dünya üzerinde kamusal mal sunumu yapacak tek bir devlet ve tek bir mutlak otorite yoktur; bu yüzden günümüz dünyasında kamu-özel ortaklıkları yaygınlaşmaktadır. Açık-şeffaf yönetim anlayışını daha da önemli hale getiren bu süreçte; devletler kamu politikası hedeflerine kanalize ettikleri teşvikleri, mali düzenleyici izleme araçlarını en az vergiler (kamu gelirleri) ve kamu harcamaları kadar etkin kullanmak durumundadırlar. Aynı şekilde sivil toplum kamu politikalarını şekillendirmede daha aktif rol oynarken, iş dünyası ve şirketler de sosyal sorumluluklar üstlenmekteler. Kısaca devletler ve devlet dişı aktörler kamu politikaları oluşturulurken daha kritik roller üstlenmekteler (Kaul \& Conceiçao, 2006a: 23).

Bugün uluslar arası ve küresel kamusal malların ulusal ve bireysel refahın merkezi haline geldiğini söylemek yanlış değildir. Kuşkusuz bunda en önemli boyut küresel kötülerle (public bads) mücadele olarak tanımlanabilir. Çünkü küresel kamusal mallar söz konusu olduğunda etki alanında görülen değişimler genellikle faydalardan çok zararların yayılması şeklinde karşımıza çıkmaktadır. 
Kamu kötüleri olarak tanımlanan negatif dışsallıkların önlenmesi için ulus devletlerin politikalarının uyumlulaştırması ve ortak çerçeve sağlayan alanlardaki çalışmalar için ulus üstü düzenlemelerin gereği hızla artmaktadır (Kaul, Grunberg, \& Stern, 1999a: 9).

Günümüzde çoğu küresel kamusal malların üretim ve finansman kararları, gelişmiş ülkeler tarafindan veya karar organlarında ağırlıklı olarak gelişmiş ülkelerin bulunduğu uluslar arası kuruluşlar tarafından verilmektedir. Sunum birçok durumda fiilen üretmek yerine ortak standartlar koymak şeklinde olmaktadır. Küresel kamusal mallar ve politikalar konusunda, gündem oluşturmak, kural koymak ve izlemek, finansman sağlamak gibi işlevleri olan uluslar arası kuruluşlar arasında en önemlisi, Birleşmiş Milletler teşkilatıdır (Kirmanoğlu, Y1lmaz, \& Susam, 2006: 33).

Soğuk savaş döneminde ABD liderliğinde kurulan bölgesel ve evrensel nitelikte örgütler, dönemin bitişiyle, önemli bir meşruiyet sorunu ile karşı karşıya kalmışlardır. Bu durum NATO gibi belirli bir bölgenin savunmasını üstlenmiş bir örgüt açısından geçerli olduğu gibi, küresel nitelikli bir örgüt olan BM açısından da geçerlidir (Emiroğlu, 2006: 61). Belki de bu nedenle Birleşmiş Milletler varlığını devam ettirebilmek adına yenidünya düzeninin içinde yeniden konumlanmış ve küresel ölçekli sorunların çözümüne yönelik politikalar geliştirilmesi sürecinde önemli roller üstlenmiştir.

\section{Küresel Kamusal Malların Sınıflanması}

Küresel kamusal malların optimal ölçekte sunumunun sağlanması için bu malların sınıflandırılması aşamasında karşılaşılan güçlüklerin iyi analiz edilmesi ve bunun sonucu finansman açısından paydaşların iyi belirlenmesi çözüme katkı sağlayacaktır.

Kaul (1999) tarafından yapılan sınıflamada daha çok geleneksel küresel kamusal mallar ve yeni küresel kamusal mallar olarak iki farklı anlayış ön plana çıkmaktadır. Sandler'in (1999) yaptı̆̆ 1 sınıflamada ise malların kuşaklararası faydalarının olması ilk ayrım noktasıdır. İkinci olarak da dışsallıklarının bir bölge ya da tüm dünyaya yayılmış olması gelir (Sandler, 1999: 22).

Görüldüğü üzere küresel kamusal malların sınıflanması esnasında farklı yazarlar, farklı görüşleri ile değişik kriterleri önemsemişlerdir. Sınıflama esnasında bazen de faydanın ya da zararın yayılma alanına vurgu yapılmaktadır. Örneğin bir ülkenin ya da birkaç ülkenin dışsallıkları içselleştirdiği durumlar, yerel ya da bölgesel kamusallığı temsil ederken, dünya üzerindeki pek çok ülkenin ya da tüm yeryüzünün etkilendiği durumlar ise uluslar arası ya da küresel kamusallığ 1 doğurmaktadır. Günümüzde genel anlamda kabul gören sınıflama sistematiği beş ana başlık altında toplanabilir.

- Kamusal Malların Fonksiyonlarına Göre Yapılan Sınıflama: Küresel kamusal malların ortaya çıkan faydalarına yönelik olarak yapılan bu sınıflama türünde; çevre, sağlık, finansal istikrar, barış ve güvenlik, serbest ticaret ve bilgi başlıkları genel olarak literatürde tüm yazarların ele aldıkları ana başlıklar olarak karşımıza çıkmaktadır.

- Kamusal Malların Kamusallık Karakterine Göre Yapılan Sınıflama: Kamusal mallarda olduğu gibi Küresel Kamusal Mallarda da sunumu yapılan mal ya da hizmetin kamusallık boyutu önem arz eder. Dışlanamazlık ve rakip olamama özelliklerini taşıyan mallar tam kamusallık arz ederken; tüketimde dışlama ya da rekabetin kısmen de olsa olduğu mallar yarı kamusal mal olma özelliğindedir. Bunun yanında dışlama yapılabilen mallar kulüp malları olarak anılırlar. 
- Kamusal Malların Karakterine Göre Yapılan Sınıflama: Eğer bir malın tanımlanması esnasında zorluk yoksa yani elle tutulur nitelikler ön plandaysa söz konusu mal somut bir küresel kamusal mal olarak tanımlanır. Aksi durumda, yani malın tarifinde hayali, elle tutulamayan faktörler daha ön planda ise bu kez soyut bir küresel kamusal maldan bahsediliyor demektir. Çevre somut mallara örnek iken, finansal istikrar soyut mallara örnek verilebilir. Küresel Kamusal Malların somut veya soyut olma özellikleri yanında, bu malların kendiliğinden var olması, sonradan üretilmesi ya da politik kararların sonucu ortaya çıkmış olması gibi özellikleri de göz önüne alınarak şu şekilde bir ayrıma da gidilebilir (Kaul, Grunberg, \& Stern, 1999b: 452);

a. Doğal Küresel Ortak Mallar (Aşırı tüketim sorunu doğabilir)

b. İnsan Yapısı Küresel Ortak Varlıklar (Tüketiminde kısmen dışlanabilme durumu vardir)

c. Küresel Politik Sonuçlar (Sunum eksikliği nedeniyle katlanılması zorunlu kamusal kötüleri doğuran olaylardır)

- Kamusal Malların Toplam Sunum Teknolojileri Kriterine Göre Yapılan Sınıflama: Küresel bir kamu malının sunumu esnasında, bütün düzeylerdeki aktörlerin katkıları arasındaki ilişkilere göre yapılan sınıflama, toplam teknoloji kriterine göre yapılan sinıflamadır.

a. Toplama Tekniği: Bu yöntemde toplam kamusal mal sunumu ya da kamusal zarar düzeyi, tüm birimlerin katkılarının toplamına eşittir. Yani ulusal kamu malları birleşerek uluslar arası kamu mallarını da oluşturur. (Kaul \& Conceiçao, 2006b: 24).

b. En İyi Vuruş Tekniği: Söz konusu malın sunum düzeyinin bu malı en yüksek miktarda sunan ülkenin sunumuyla ifade edildiği durumdur. Toplama yönteminin aksine bir aktörün katkısı, diğerinin yerine aynı katkıyı sağlamaz. Toplam kamu malı miktarı bu malı en çok sunan aktörün sunum miktarı kadardır (Akdemir \& Şahin, 2006: 7).

c. En Zayıf Halka Tekniği: Bu teknikte anlatılmaya çalışılan, sunum esnasında en az katkıyı yapan aktörün sunum miktarı ile sınırlı kalan bir miktardan bahsediliyor olunuşudur. Örneğin bir salgın hastalık olduğunda en az önlemi alan ülke diğerlerinin aldığı önlemlere rağmen sonuç alınması noktasında başarısızlığa neden olacaktır. Bu durumda en zayıf halkaya yönelmek, küresel kamusal mal sunumunu artıracaktır (Kirmanoğlu, Yilmaz, \& Susam, 2006: 30).

d. Ăğırlıklı Toplama Tekniği: Bu yöntem toplam öncesi bireysel katkılara uygulanan ağırlıklar hariç olmak üzere toplama tekniğine benzer. Daha esnek olan bu teknik, bir ülkenin göreli coğrafi konumu ve büyüklügü gibi faktörleri de göz önüne alır (Akdemir \& Şahin, 2006: 7).

- Kamusal Malların Diğer Özelliklerine Göre Yapılan Sınıflama: Küresel kamusal mallar yeni bir kavramdır ve sınıflanması esnasında çok farklı kriterler dikkate alınarak çalışmalar yapılmaktadır. Örneğin Dünya Bankası sınıflama yaparken malları 'çekirdek mallar' ve 'tamamlayıcı mallar' olarak ikiye ayırmaktadır. Bu sınıflama şekline göre salgın hastalıkların önlenmesi 'çekirdek' niteliğinde bir kamusal mal iken; yoksulluğun önlenmesi ve genel sağlı hizmetleri gibi ulusal düzeydeki hizmetler ise 'tamamlayıcı' nitelikteki küresel kamusal mallardır (Kirmanoğlu, Yılmaz, \& Susam, 2006: 30).

Kaul vd. (1999) çekirdek malları uluslar arası çaba ile ortaya konan bir somut mal ya da politika olarak tanımlarken; tamamlayıcı malları bu politikalara ya 
da mallara ulaşmanın bir destekleyicisi olarak görmektedirler (Kaul, Grunberg, \& Stern, 1999a: 13).

\section{Karayolu Trafik Güvenliği Kavramı ve Karayolu Trafik Güvenliği Sorununa Küresel Çözüm Arayışları}

Ulaşım insanların, hayvanların, eşyaların bulundukları yerlerden farklı bir yere aktarılmasıdır (Kuyzu \& Tekin, 2013: 4). Ulaştırma sektörü, kendi içinde direkt olarak üretim yapan bir sektör olarak görülmese de hizmet sektörü içinde yer alan; yarattığı ekonomik, sosyal ve kültürel etkileriyle, bireyleri ve toplumların yaşantısını doğrudan etkileme gücüne sahip bir sektör; hatta dinamik ve sistemli bir organizasyondur. Her organizasyonda olduğu gibi ulaştırma sektöründe de bir takım dişsallıklar ve arz ve taleple ilgili denge gereksinimi ortaya çıkmakta, yerel politikalar yanında uluslar arası gelişmeler de sektör içi dengeleri etkileyip değiştirmektedir.

Ulaşım sektörünün oluşturduğu dışsallıklar bireyler ve toplumları olduğu kadar, ekolojik dengeyi bozması nedeniyle gelecek nesilleri de tehlikeye atacak boyutlara varmıştır. Bunun altında yatan temel sebep ise, ulaştırma modları arasında yaşanan dengesiz dağılım ve karayolları aracılığıyla yapılan ulaşım faaliyetlerinin tüm dünyada ve özellikle gelişmekte olan ülkelerde, ulaştırma sektörü içinde çok dengesiz bir şekilde ön plana çıkıyor olmasıdır. Oysa içinde çeşitli ulaşım biçimlerini barındıran bir ulaşım sistemi yıkımlara ve kargaşalıklara karşı daha dayanıklıdır (Freund \& Martin, 1996: 249).

Taşıma modlarının kullanım oranlarının son 30 yıl içerisindeki değişimine bakıldığında, tüm dünyada demiryolu ve iç suyolları taşımacılığından karayolu taşımacılığına doğru bir kayma olduğu dikkati çekmektedir (Kuyzu \& Tekin, 2013: 17).

Karayolu ulaşımı günümüzdeki en yaygın ulaşım şeklidir. Bu sebeple karayolu trafiğini kullananlar bu platformun güvenli hale getirilmesinden hem sorumludur, hem de sonuçları açısından etkilenmektedir. Bu durum Viyana Konvansiyonu'nun (1968) 7. maddesinde 'Yol kullanıcllarl, trafiği tehlikeye düşürecek veya kamu veya özel mülke zarar verebilecek her türlü davranıştan kaçınacaktır' şeklinde ifade edilmiştir. Ülkemizde 2918 sayılı Karayolları Trafik Kanunu'nun 3. Maddesi'ne göre Trafik; yayaların, hayvanların ve araçların karayolları üzerindeki hal ve hareketleridir (Resmi Gazete, 1983).

Karayolu Trafik Güvenliği'nin geliştirilmesi ve bu alandaki yükün diğer ulaşım alt sektörlerine dağıtılması son yıllarda ulaştırma sektörü açısından çözülmesi gereken en önemli sorun olarak karşımıza çıkmaktadır. Karayolu Trafik Güvenliği alanında yaşanan olumsuzlukların ve özellikle de karayollarında oluşan trafik kazalarının önlenmesi bütün dünya devletlerinin üzerinde çalıştıkları bir olgu olduğu halde, günümüzde bu sorunu tamamıla çözebilmiş bir ülke bulunmamaktadır. DSÖ (2015) verilerine göre 2013 yılı itibariyle 1,25 milyon olan trafikteki ölü sayısı, 2007 yılından beri ölüm oranının neredeyse sabit bir seyir izlediğini göstermektedir. Ancak, küresel çapta son üç yılda gerçekleşen \% 4 oranındaki nüfus artışı ve motorlu araç sayısında görülen \% 16 oranındaki artış göz önüne alındığında karayolu güvenliğini artırma amaçlı geliştirilen önlemlerin işe yaradığ 1 da değerlendirilebilir. Yine de küresel hedef olan, 2020 yılı itibariyle trafik çarpışmalarına bağlı ölümlerin \% 50 oranında azaltılması hedefinden epey uzak kalındığı açıkça görülmektedir (Durna, 2015).

Karayolu trafik hasarları, ekonomik ve insanî kalkınmadaki gelişmeleri tehdit etmektedir. Karayollarında meydana gelen trafik kazalarının Türkiye'ye maliyeti yılda yaklaşık 20 milyar liradır (Lorasokkay, Çelik, \& Atasağun, 2013: 2). Karayolu trafik hasarlarına bağlı 
yıllık küresel kaybın yaklaşık olarak 1 trilyon 850 milyar dolar olduğu tahmin edilmektedir (Brasilia Deklarasyonu, 2015). Semiz vd. göre (2012) trafik kazalarında yaşanan kayıpların dünya genelinde, hükümetler açısından ortalama olarak gayri safi milli hâsılanın $\% 1$ ile \% 3'ü arasında olduğu tahmin edilmektedir. Kimi düşük ve orta gelirli ülkelerde kayıp; aldıkları kalkınma desteğinin toplam miktarından daha büyüktür (Semiz, Çelik, \& Vursavaş, 2012: 55).

DSÖ dünya üzerinde ki ölüm sıralamasında sekizinci sırada yer almakta olan karayolu trafik kazaları sebebiyle gerçekleşen ölümleri küresel bir halk sağlığ sorunu olarak tanımlamaktadır (WHO, 2015a).

DSÖ (2013) verilerine göre, bugün yalnızca 28 ülke vatandaşları (449 milyon kişi) yani dünya nüfusunun sadece $\%$ 7'si beș temel risk faktörleri üzerine geniş kapsamlı yasal mevzuatla korunmaktadır (WHO, 2013: viii). Söz konusu temel risklerin ortadan kaldırılmasına yönelik farkındalık oluşturacak küresel ölçekli çalışmaların artması geriye kalan \% 93'lük nüfus için önemlidir.

Yol güvenliği aracın, sürücünün ve karayolu altyapısının dikkate alındığı üçlü bir yapı ile sağlanabilir. Karayolu trafik güvenliğinin eksikliği tüm dünyadaki devletler, örgütler ve insanlar için acil çözüm ihtiyacı gereken bir alandır. Bu bağlamda konunun geniş kitleleri ilgilendirmesinden ve karayollarının kamusal alan olmasından hareketle Küresel Kamusal Mallar sistematiği ile yol güvenliğini artırıcı hizmetleri ilişkilendirmek mümkündür.

\section{Küresel Kamusal Malların Sınıflanma Kriterleri Açısından Karayolu Trafik Güvenliği Hizmetleri}

Günümüzde Karayolu Trafik Güvenliğini artırıcı hizmetler; trafik kaza ve sıkışıklıklarının azaltılmast, mühendislik faaliyetleri ve yasal düzenlemeler şeklindedir. Bu hizmetlerin etkilerinin sınıflaması da şu şekilde yapılmaktadır;

- Trafik kazası ve sıkışıklarının azaltılması açısından,

- Sosyal ve Ekonomik Maliyetlerde Dışsallıkların Önlenmesi

○ İşüucü ve İnsan Kaybının Önlenmesi

- Piyasa Rekabeti için Olumsuz Etkilerin Ortadan Kaldırılması

- Kamu Sağlığına Olumsuz Etkilerin Önlenmesi

- Mühendislik Faaliyetleri açısından,

- Yol Standartlarının Geliştirilmesi

- Araç ve Güvenlik Standartlarının Geliştirilmesi

- Yasal Düzenlemeler açısından,

- Sürücü Olma Şartlarında Yapılan Düzenlemeler

- Araç Standartlarında Yapılan Düzenlemeler

- Mesleki Yeterlilik Eğitimine Yönelik Çalışmalar

- Çalışma ve Dinlenme Sürelerinin Düzenlenmesi,

amacıyla yapılan çalışmalar yol güvenliğini artırıcı etkilere sahiptir. Sayılan sebeplerden günümüz dünyasında politik karar alma sürecinde ulaşım planlaması yapılması bir gerekliliktir. $\mathrm{Bu}$ planlama esnasında ele alınacak farklı ulaşım modları arasındaki entegrasyon da önemini artırmıştır. Bunların gerçekleşmesi için mühendislik faaliyetleri kadar medya ve sivil toplum desteği ile sosyal bilinçlenme de gereklidir. Kısaca günümüzde yol güvenliğini artırmanın sadece yeni yol arzı ile mümkün olmadığı açıça anlaşılmaktadır. 
Bu sebeple kamusal kaynaklar sadece yol yapımı ve yenilemesi açısından değil daha farklı şekillerde de etkin kullanılmaya yöneltilmelidir.

Küresel Kamusal Mallar söz konusu olduğunda, sunumun kamusallık ölçütü, etkinin yayılma alanının boyutu, sunumu yapanın niteliği, sektörel açıdan sunum tekniği ve etkilerin teknolojik değerlendirilmesinin analizi gibi karmaşık bir yapı içinde analiz yapılması zorunluluktur.

\subsection{Küresel Kamusal Malların Kamusallık Karakteri Kriterine Göre Karayolu Trafik Güvenliği Hizmetleri}

Karayolu Trafik Güvenliği ile ilgili hizmetler bütünü sadece yol kullanıcılarını değil, bugünün dünyasındaki insanların pek çoğunu doğrudan etkileyen sonuçlar içermektedir. Küreselleşme ve şehirleşmenin yaygınlığ 1 bunu destekler mahiyettedir. Örneğin şehirleşmenin yaygınlaşması sebebiyle artan trafik yoğunluğu sadece yol kullanıcılarının değil aynı zamanda kentlerde yaşayan herkesin hava kirliliğinden rahatsız olması sonucunu doğurmaktadır.

Bu çalışmalar aynı zamanda nesiller arası etkiler de içermektedir. Özellikle insan ve işgücü kaybından kaynaklanan nesiller aras1 etkiler önemle üstünde durulmas1 gereken boyutlarda olduğu için pek çok ulus üstü kuruluşlar da konuyu gündemlerine almıştır. Zira vasıflı işgücünün korunması, ülkelerin rekabetçi piyasa şartlarında geri düşmesinin önlenmesi açısından olduğu kadar, kalkınma ve gelişmeleri açısından da önem arz etmektedir.

Yol güvenliği alanında alınacak önlemlerle hem bugünün dünyasında hem de gelecek nesillerin yaşamlarında elde edilecek faydalar; ya da bu tedbirlerin alınmaması durumunda katlanılacak maliyetler açısından dışlanamazlık söz konusudur. Zira oluşan dişsallıklar yol kullanıcıları haricinde kamusal etkiler ortaya koymaktadır. Trafik Güvenliğinin yeterince etkin sağlanamaması nedeniyle ortaya çıkan ekonomik maliyetler, finansal hayata yansıyan istikrarsızlıklar, çevresel felaketlerin gezegenimizin pek çok bölgesinde yaygınlaşması, çocuk yaşta yaşanan ölümler ve ailesiz kalan çocuklar bunun örneklerindendir.

$\mathrm{Bu}$ sebeplerle Karayolu Trafik Güvenliği kavramının dışlanamazlık ve rakip olmama özellikleri yanında KKM'ların sınıflama kriterlerinden Kamusallık Karakteri ölçütü açısından, sadece nesil içi değil nesiller arası etkileri de gözlenebildiğinden, KKM olma özelliklerini karşıladığı görülmektedir.

Aşağıda yer alan Şekil-1'deki bilgiler de buraya kadar anlatılanları destekler niteliktedir. Sandler (1999) tarafından yapılan kamusallık karakteri ölçütü sınıflamasına Susam (2008) tarafından yapılan katkıları da dikkate alarak tarafımızdan oluşturulan Şekil-1'de Trafik Güvenliği alanında sunulan hizmetler örneklenip; hem kısa vadede bugün yaşayan insanlar açısından, hem de uzun vadede gelecek nesillere etkileri açısından yol güvenliği alanında yapılan çalışmalar sınıflanmıştır

Bu sınıflama esnasında sunumu yapanın niteliği de dikkate alınmıştır. Zira bazı faaliyetler tam kamusal özellik arz ederken, bazı hizmet sunumları tamamlayıcı nitelikte ya da kulüp malı niteliğinde olabilmektedir. Bazen de ortaya çıkan fiili durum üretime katılma şeklindedir. 


\begin{tabular}{|c|c|c|c|c|c|}
\hline & Tam Kamusal Mallar & $\begin{array}{c}\text { Tamamlayıcı } \\
\text { Mallar }\end{array}$ & Kulüp Mallar & $\begin{array}{l}\text { Üretime } \\
\text { Katılma }\end{array}$ \\
\hline \multirow{2}{*}{ 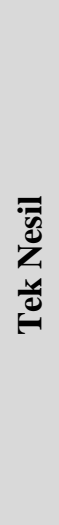 } & 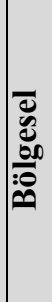 & $\begin{array}{l}\text { Ulaştırma Planlaması } \\
\text { Çalışmaları, } \\
\text { Mevzuat Düzenlemeleri } \\
\text { (Hız, Alkol Kullanımı, } \\
\text { Emniyet Kemeri vb.) }\end{array}$ & $\begin{array}{l}\text { Yasal Zorunluluk } \\
\text { Olmayan Koruyucu } \\
\text { Tertibat Kullanımı } \\
\text { (ABS, Hava } \\
\text { Yastığı vb.) }\end{array}$ & $\begin{array}{l}\text { Sigortacilık } \\
\text { Faaliyetleri }\end{array}$ & $\begin{array}{l}\text { Trafik } \\
\text { Güvenliği } \\
\text { Platformları, } \\
\text { Internet } \\
\text { Siteleri, } \\
\text { Okullar, } \\
\text { STK'lar }\end{array}$ \\
\hline & 樆 & $\begin{array}{l}\text { Küresel Bilgi Paylaşımı } \\
\text { (30 gün takip sistemi } \\
\text { vb.), } \\
\text { Mevzuat Yaygınlaştırma } \\
\text { Faaliyetleri }\end{array}$ & $\begin{array}{l}\text { Sürücü Okulları, } \\
\text { Mesleki Yeterlilik } \\
\text { Eğitim Merkezleri }\end{array}$ & $\begin{array}{l}\text { STK } \\
\text { Faaliyetleri }\end{array}$ & $\begin{array}{l}\text { Enstitüler, } \\
\text { Üniversiteler }\end{array}$ \\
\hline \multirow{2}{*}{ 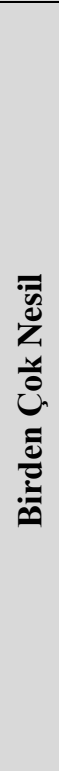 } & 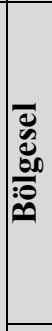 & $\begin{array}{l}\text { Yol Arzı (Duble yol, } \\
\text { Otoyol, Geometrik } \\
\text { Standartlarda } \\
\text { İyileştirme), Eğitim } \\
\text { Faaliyetleri, Sağlık ve } \\
\text { İlkyardım, } \\
\text { Sürücü Sicil Kayıtları, } \\
\text { Araç Tescil İşlemleri }\end{array}$ & RS-10 Projesi & $\begin{array}{l}\text { TRACECA } \\
\text { Koridoru, } \\
\text { TEN-T Ulaşım } \\
\text { Ağları }\end{array}$ & $\begin{array}{l}\text { DB Hibe ve } \\
\text { Kredileri }\end{array}$ \\
\hline & 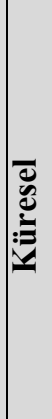 & $\begin{array}{l}\text { Çevre ve Sağlık } \\
\text { Regülasyonları, } \\
\text { Kamu Sağlığı, } \\
\text { İşaretleme ve Güvenlik } \\
\text { Standartlarında Yasal } \\
\text { Düzenlemeler }\end{array}$ & $\begin{array}{l}\text { STK Faaliyetleri, } \\
\text { Mühendislik } \\
\text { Faaliyetleri }\end{array}$ & $\begin{array}{l}\text { EuroNcap } \\
\text { Testleri, } \\
\text { AETR } \\
\text { Konvansiyonu, } \\
\text { ILO 153 Nolu } \\
\text { Sözleşme, } \\
\text { OECD-IRTAD } \\
\text { faaliyetleri, } \\
\text { Viyana } \\
\text { Konvansiyonu }\end{array}$ & $\begin{array}{l}\text { IRTAD, } \\
\text { ASIRT, } \\
\text { IRAP vb. } \\
\text { oluşumlar }\end{array}$ \\
\hline
\end{tabular}

\section{Şekil 1 Trafik Güvenliğini Artırıcı Hizmetlerin Kamusallık Ölçütüne Göre Küresel Kamusal Mal Sinıflamasına Uyarlanması}

Şekil-1'de tam kamusal mallar şeklinde ifade edilen sütunda yer alan hizmetlerin ortak özelliği sunumu yapan birimin kamu erkini temsil ediyor olmasıdır. Bu bazen bir yerel hükümet bazen de yerel hükümetlerin katılımı ile oluşan ulus üstü bir organizasyon olabilmektedir. Örneğin; ulaştırma planlamasına yönelik çalışmalar ve mevzuat düzenlemeleri öncelikle yerel, ardından bölgesel anlamda trafik güvenliğine olumlu etki edecektir. Küresel ölçekte trafik güvenliğini artırmak için ise bilgi paylaşımı ve mevzuat düzenlemelerinin yaygınlaştırılması fayda sağlayacaktır.

Trafik güvenliğini artırıcı hizmetlerin etkilerinin birden fazla nesli etkilediği eğitim faaliyetleri örneğinde görülmektedir. Aynı şekilde bölgesel faydanın nesiller arası etkilerinin daha sıklıkla görüldüğü bir başka konu da yol arzı ve yol standartlarının geliştirilmesi çalışmalarıdır. 
Çevre ve sağlık alanında geliştirilen regülasyonlar ise hem nesiller arası etkileri hem de küresel boyutta sonuçları olan hizmetlerdendir.

Şekil-1'de yer alan tamamlayıcı mallar ana başlığındaki hizmetlerin de yerel, bölgesel ya da küresel etkileri söz konusudur. Araçlarda emniyet kemeri ve kask gibi yasal olarak kullanımı zorunlu olmayan, güvenlik artırıcı tertibatlar kullanılması, sürücü ve şoförlere yönelik eğitim faaliyetleri daha çok tek nesil etkilere sahip görünmektedir. Bunun yanında gönüllü olarak trafik güvenliği alanında çalışan bazı STK'ların faaliyetleri birden çok neslin fayda sağlayacağı sonuçları doğurmaktadır.

Şekil-1'de Kulüp Mallar başlığı altında sayılan örneklerin de tek bir nesil ya da nesiller arası boyutlarda sonuçlar doğurduğu görülmektedir. Şekilde sigortacılık faaliyetleri tek nesli ilgilendiren sonuçlar doğuran kulüp mallar arasında sayılmıştır. Kulüp mallar içinde bazı STK faaliyetlerinin sayılmasına sebep olan ise ETSC ve ERF gibi örneklerde karşımıza çıkan STK'ları da kapsayan işbirliği halindeki çalışmalardır. Avrupa genelinde karayolu güvenliği politikası alanında iki organizasyon etkinlik sürdürmektedir. Bunlar Avrupa Ulaşım Güvenliği Konseyi (European Transport Safety Council, ETSC) ve Avrupa Birliği Yol Federasyonu (European Union Road Federation-ERF) olarak adlandır1lır. Bu organizasyonların içinde, Sivil Toplum Kuruluşları güç birliğini sağlamak amacıyla bulunmaktadır (Wegman, 1996: 12). Ancak bu organizasyonlar özünde AB nezdinde faaliyette bulundukları için rakip olmama ve dışlanabilme özellikleri açısından kulüp malı kriterlerine de uyduğu görülmektedir.

Şekil-1'de birden çok nesli etkileyen bazı kulüp malı örnekleri sayılırken AETR Konvansiyonu, Viyana Konvansiyonu örnekleri de verilmiştir. Çünkü bu örnekler de bir üye olma süreci ve bazı maliyetlerin üstlenilmesi karşılığında fayda elde edilmesi sonucu doğduğundan kulüp mallarının özelliklerini taşımaktadır. Ülkemizde ehliyet sisteminde yapılan 2013 yılı sonrası düzenlemeler Viyana Konvansiyonu'na üyeliğimizin gerçekleşmesi sürecini; 2004 yılında 39 adet trafik levhasının şeklinin değiştirilmesi ise AB uyum sürecinde gerçekleşen değişiklikleri örneklemektedir.

Şekil-1'de yer alan bir diğer sütun da ise üretime katılma başlı̆g yer almıştır. Bu başlık altındaki hizmetlerin sunulması sonrası görülen etkiler de güvenliği artırıcı etkiler içermektedir. Örneğin üniversite ya da enstitülerin bilimin her alanında olduğu gibi yol güvenliği alanında da çalışmalar yapması küresel ölçekte sorunun çözümüne katkı sağlayacaktır. IRTAD'ın OECD bünyesinde yapmış olduğu veri tabanı çalışmaları da aynı şekilde küresel ölçekte bir başvuru kaynağı olarak yol güvenliği alanında çalışmalara ışık tutmaktadır. TISPOL tarafindan yürütülen faaliyetler de birden çok nesli etkileyen bölgesel etkilere sahip, yol güvenliği üzerine olumlu etkileri olan hizmetlerdir. TISPOL örgütü Avrupa yollarında yol güvenliği ve kolluk uygulamalarını geliştirmek amacıyla Avrupa trafik polis güçleri tarafından kurulmuştur. Kuruluş amacı karayolundaki ölüm ve yaralanmaları azaltmaktır (TISPOL, 2015a).

\subsection{Küresel Kamusal Malların Fonksiyonları Kriterine Göre Karayolu Trafik Güvenliği Hizmetleri}

a. Çevre ve Sağglı ana başlıkları açısından; Emisyon artışından kaynaklanan ekolojik dengedeki bozulmalar kamu sağlığını direkt olarak tehdit ederken, gelecek nesiller için de tehlike arz etmektedir. Aynı şekilde oluşan kazalar sebebiyle kaybedilen işgücü ve maddi varlıklar da hem toplumların piyasadaki rekabet gücünü olumsuz etkiler hem de bireysel olarak ilave maliyetlerin yüklenilmesine sebep olur. Ayrıca 
otomotiv sektörü açısından en bağlayıcı ve önemli regülasyonlar çevre ve insan sağlığına etkisi ile araç satılabilirliğine direkt etkileri nedeniyle gaz salınımı ile ilgili egzoz emisyon değerleridir. Egzoz emisyon değerleri yasalarla belirlenmiş sınırlar içinde olmak zorundadır (Alkan, Karaca, \& Aladağ, 2011: 602-603).

b. Barış ve Güvenlik alanındaki etkiler; Büyüyen ve toplumların ekonomik hayatları açısından önemini gitgide artıran ulaşım sektöründe yol güvenliği kavramının, barış ve güvenlik kavramları ile direkt olarak ilişkisi olmasa da, dolaylı olarak çevreye, sağlığa, serbest ticaret ve finansal istikrara etkileri olduğu görülmektedir. Diş ticaretin geliştiği, sermaye dolaşımı için sınırların esnekliğinin arttığı bir dünyada barışa olan ihtiyacın daha fazla hissedilmesi kaçınılmazdır. Ayrıca Uluslararası Çalışma Örgütü'nün ana sözleşmesinde ifadesini bulduğu üzere; evrensel ve kalıcı bir barış ancak sosyal adalet temelinde gerçekleşebilir. İnsanlar açısından adaletsizliğin, sefaletin ve yoksulluğun engellenemediği çalışma koşullarının oluşması evrensel barış ve ahengi tehlikeye düşürecektir (Kapar, 2007). Ülkeler küresel entegrasyon ile uluslar arası rekabet şartlarını olumlu kullanmak açısından ve kalkınmışlık farklarından kaynaklanan gelir dağılımı eşitsizliklerinden kurtulmak için yol güvenliği ile birlikte sağlıklı işleyen bir ulaşım sektörü kurgulama çabasında olmaktadır. Hem küresel anlamda hem de yerel hükümetler açısından yol güvenliği kavramının barış ve güvenlik alanlarında dolaylı etkileri görüldüğü için KKM sistematiği içinde anılması söz konusudur.

c. Serbest Ticaret ve Finansal İstikrar açısından; Yol güvenliğinin artması ticari alandaki gelişmeleri olumlu etkilemektedir. Gelişen ticaretin de çoğu zaman daha etkin bir istikrar sağlama yönü bulunmaktadır. Karayolu taşıtlarının üretim ve pazarlama süreci dünya ekonomisi açısından önemli yer tutmaktadır. Otomotiv sanayi birçok ülkede diğer sektörlerin teknoloji düzeyine ve toplumun gelişimine önemli bir katkı sağlamaktadır. Dünyada 2015 yılı için otomobil sektörü açısından toplam araştırma, geliştirme ve üretim yatırımları yaklaşık 85 milyar Euro tutarındadır. Araç üretim ve kullanımı ise yalnız yirmi altı ülkede 430 milyar Euro dolayında vergi gelirlerine kaynak yaratmaktadır (OICA, 2015b). Trafik Kazalarından doğan maliyetler ve bunun önüne geçilmesi amacıyla yapılan diğer kamusal harcamaları da düşündüğümüzde, yol güvenliğinin artırılması çalışmalarında alınacak olumlu sonuçların, kamusal kaynakların kullanımı açısından etkinlik sağlayacak önemli bir unsur olduğu gözlemlenmektedir.

d. Bilgi ana başlığı açısından; sağlıklı veri birikiminin ve paylaşımın sorun çözmede katkısı nedeniyle trafik güvenliği alanındaki her türlü hizmetin kalite ve yaygınlık ölçütüne katkı sağlayacağı öngörülebilir. Ayrıca bireysel planda ele alındığında araçlar ve hayvanlarla birlikte trafiğin üç unsurundan biri sayılan insanların, sosyal bir ortam olan trafik ortamında, hangi şartlarda hareket edeceği ile ilgili bilgiler ile donatılması demek olan eğitimler, trafik güvenliğinin sağlanması açısından önemlidir. Bireylerin eğitimini sadece sürücü kursları aracılığıyla, sürüş için yapılan yetişkin eğitimi olarak ele almamak gerekir. Okullarda sağlanan formel eğitim yanında, sivil toplumun katkısıyla yapılan bilinçlendirme çalışmaları ve medya destekli kamuoyu aktiviteleri de bu eğitimler içinde önemli yer tutmaktadır. Ayrıca taşı güvenliğinin artırılması yol güvenliğinin artırılmasına da olumlu yansıyacağı için buna yönelik mühendislik faaliyetlerinin artırılması ve elde edilecek sonuçların yasal düzenlemelerle yaygınlaştırılması da bilimsel açıdan bir gerekliliktir. 


\subsection{Küresel Kamusal Malların Karakteri Kriterine Göre Karayolu Trafik Güvenliği Hizmetleri}

Karayolu trafik güvenliğini artırıcı hizmetlerin küresel kamusal malların karakterine göre yapılan sınıflamasında şu sonuçlar ortaya çıkmaktadır;

Trafik kazaları ve tıkanıklıkları sebebiyle oluşan sosyal ve ekonomik maliyetler doğal küresel ortak varlıklar üzerinde dolaylı etkilere sahiptir. Piyasa rekabeti ile işgücü ve insan kaybı alanındaki ilgi derecesi düşük iken, kamu sağlığı açısından direkt bir ilgi olduğu görülmektedir. Örneğin emisyonu artıran trafik tıkanıklıkları kamu sağlığını tehdit eden en önemli unsurların başında gelirken, kazalar sebebiyle yaşanan maddi kayıplar toplumların ortak maliyetler yüklenmesine sebep olmakta ve küresel ortak paylaşımları dolaylı olarak etkilemektedir.

İnsan yapısı küresel ortak varlıklar ile trafik güvenliği ilişkisi ise yakından ilgili görünmektedir. Trafik Güvenliğini artırıcı faaliyetler, insan yapısı küresel ortak varlıklar açısından sosyal ve ekonomik maliyetler ortaya çıkmasına sebep olurken; işgücü ve insan kaybı ile kamu sağlı̆̆ üzerine de direkt etkilidir.

Yol güvenliğini artırıcı hizmetler, insan yapısı küresel ortak varlıklara dönük, piyasa rekabeti açısından da dolaylı etkileri içinde barındırmaktadır çünkü katlanılan maliyetler yanında negatif dışsallıkların önlenmesiyle elde edilen kazanımları da söz konusudur.

Trafik kazalarının azaltılmasına ve tıkanıklıkların önlenmesine yönelik güvenlik artırıcı hizmetler küresel politik sorunlar alt başlı̆g açısından direkt etkileri olan bir alan olarak görülmektedir. Ulus üstü kuruluş ve organizasyonlar, STK'lar ile işbirliği halinde, yerel hükümetlerce çözümünde güçlük çekilen yol güvenliği problemlerinin çözümüne yönelik pek çok çalışma yapmaktadırlar. DSÖ'nün trafik kazaları sebebiyle yaşanan kayıpları bir kamu sağlığı problemi olarak kabul etmesi ve üye ülkelere 2020 y1lına kadar kazalara bağlı ölümleri \% 50 oranında azaltmaya yönelik mevzuat düzenlemeleri yapma yönünde tavsiyede bulunan BM kararları bu alanda yapılan küresel sunuma örneklerdir.

Mühendislik faaliyetleri penceresinden bakınca doğal küresel ortak varlıklar şeklinde yapılan sınıflama ile karayolu güvenliğini artırıcı hizmetler ilgisiz görünmektedir. Ancak insan yapısı küresel ortak varlıklar açısından yapılan sınıflamada yol standartları ve güvenlik ekipmanları konusundan yapılan sunum direkt ilgilidir. Örneğin 2004 yılında ülkemizde 39 adet trafik levhasının şeklinin değiştirilmesi bunu kanıtlar niteliktedir. Ancak bu düzenlemelerin küresel çapta yaygınlığının tam anlamıyla sağlanamadığı günümüzde küresel politik sorunlar açısından sunum ile yol standartları dolaylı ilgiye sahipken, güvenlik ekipmanları açısından ilgi kurulamamaktadır.

Yasal Düzenlemeler açısından da doğal küresel ortak varlıklar ile ilişki derecesi düşüktür. Hatta araç standartlarının çevreye olan etkileri dışında bu alt başlık için ilgi kurmak mümkün değildir.

İnsan yapısı küresel ortak varlıklar yönünden araç standartları ve mesleki yeterlilik eğitimi alanında yapılacak faaliyetlerin etkileri direkt iken, sürücü olma şartları dolaylı etkiye sahiptir, ancak çalışma ve dinlenme süreleri açısından ilgisizlik söz konusudur.

Yine küresel politik sorunlar açısından yapılacak sunumları dikkate alırsak araç standartlarına yönelik regülasyonların önemi gereği direkt bir ilgi söz konusu olurken, 
sürücü olma şartları ve çalışma ve dinlenme süreleri açısından dolaylı bir etkiden bahsedilebilir. Oysa mesleki yeterlilik eğitimleri açısından ilgisizlik söz konusudur.

\subsection{Küresel Kamusal Malların Toplam Sunum Teknolojileri Kriterine Göre Karayolu Trafik Güvenliği Hizmetleri}

Karayolu trafik güvenliğini artırıcı tüm hizmetlerin Küresel Kamusal Malların toplam sunum teknolojileri açısından direkt etkilere sahip olduğu görülmektedir.

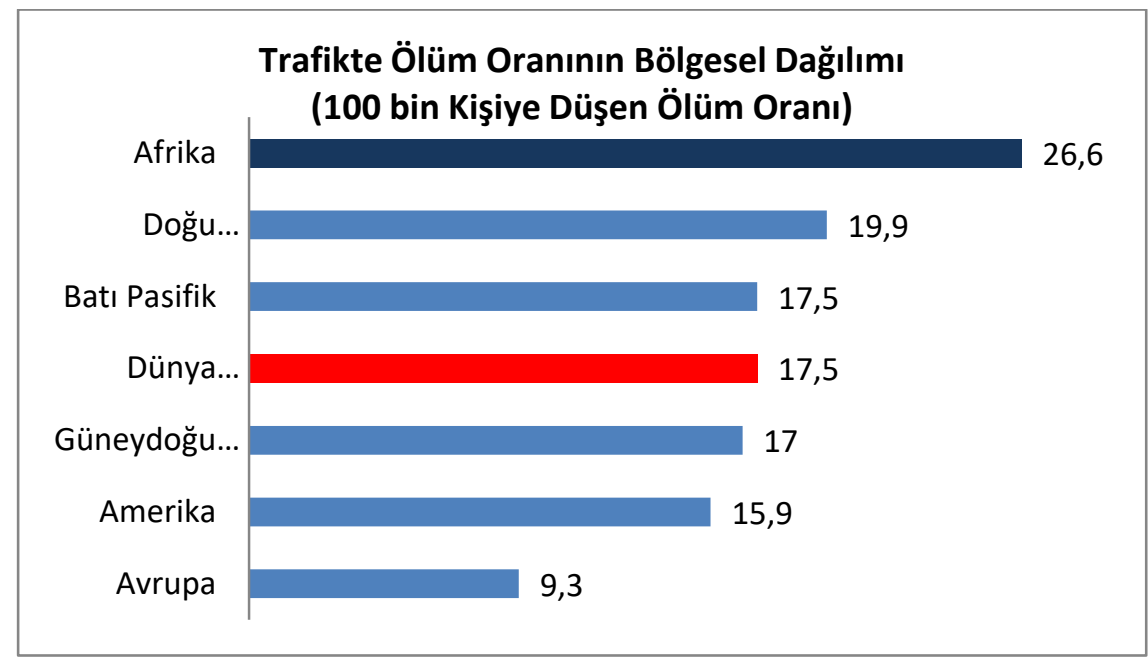

Kaynak: WHO, Global Status Report On Road Safety 2015, s.6'dan çevrilmiştir.

Şekil 2 Bölgelere Göre Karayolu Kaynaklı Trafik Ölümlerinin Dağılımı

Şekil-2'de karayolu ölümlerinde dünya ortalamasının yüz bin kişide 17,5 kişi olarak ölçüldüğü görülürken, Afrika kıtasında bu rakamın 26,6 kişiye kadar yükseldiği görülmektedir. Burada en çok dikkati çekmesi gereken ise; Afrika kıtasının motorlu araç sayısının ekonomik sebeplerden oldukça düşük olduğu gerçeğidir. Çünkü DSÖ (2015) verilerine göre yüksek gelir düzeyine sahip ülkelerde yaşayan dünya nüfusunun \% 18'lik kısmı, motorlu karayolu taşıtlarının \% 46'sına sahiptir. Orta gelir düzeyinde görülen \% 70’lik nüfusa sahip ülkeler motorlu kara taşıtlarının \% 53'lük kısmına sahiptir. Düşük gelir grubunda görülen \% 12'lik ülkelerin karayolu taşıtlarının sadece \% 1'lik kısmına sahip olduğu görülmektedir (WHO, 2015b: 4).

Şekil-2'de ortaya çıkan tablo gereği yol güvenliği açısından acil önlemlerin dünya genelinde yaygınlaştırılması kadar farklı bölgelerde farklı şekilde hizmet sunumu yapılması da gereklidir. KKM'ların sunumu söz konusu olduğunda bahsi geçen toplama tekniği, en iyi vuruş tekniği, en zayıf halka tekniği ve ağırlıklı ortalama tekniğinin yol güvenliği alanıyla direkt ilgileri bu açıdan önemlidir.

KKM'ların toplam sunum teknolojileri ile trafik güvenliği ilişkisi Şekil-3'de açıklanmıştır. Şekil-3'de Kanbur ve Sandler'in (1999) yaklaşımına göre KKM'ların sınıflaması esas 
alındığında karayolu güvenliğini artırıcı bazı faaliyetlerin ulusal, bölgesel ya da küresel ölçekte dağılımı şu şekildedir;

\begin{tabular}{|c|c|c|c|}
\hline & Toplama Tekniği & En İyi Vuruş Tekniği & En Zayıf Halka Tekniği \\
\hline 跑 & $\begin{array}{l}\text { Şehir içi ulaşımını } \\
\text { rahatlatma } \\
\text { T1kanıklıklarla } \\
\text { mücadele }\end{array}$ & $\begin{array}{l}\text { Yol ve işaret } \\
\text { standartlarının } \\
\text { geliştirilmesi } \\
\text { faaliyetleri } \\
\\
\text { Trafik Eğitim } \\
\text { Faaliyetleri } \\
\end{array}$ & $\begin{array}{l}\text { Maddi kayıplar } \\
\text { Ölüm ve yaralanmaya } \\
\text { dayalı işgücü kayıpları }\end{array}$ \\
\hline 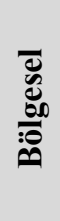 & $\begin{array}{l}\text { Ulaştırma modları } \\
\text { arasında } \\
\text { uyumlulaştırma } \\
\text { çalışmaları }\end{array}$ & $\begin{array}{l}\text { TRACECA } \\
\text { Koridoru } \\
\text { TEN-T Ulaşım } \\
\text { ağları projeleri vb. } \\
\text { çalışmalar }\end{array}$ & $\begin{array}{l}\text { Korunmasız yol } \\
\text { kullanıcıları açsından } \\
\text { alınacak önlemler (Az } \\
\text { gelişmiş ülkeler-Afrika) }\end{array}$ \\
\hline 离 & $\begin{array}{l}\text { Vergileme ve } \\
\text { Regülasyonların } \\
\text { yaygınlaştırılması } \\
\text { çalışmaları }\end{array}$ & $\begin{array}{l}\text { BM (DSÖ- } \\
\text { ASIRT), OECD } \\
\text { (IRTAD) gibi } \\
\text { trafik güvenliği } \\
\text { faaliyetleri }\end{array}$ & $\begin{array}{l}\text { Geliştirilmiş araç } \\
\text { güvenlik standartlarının } \\
\text { yaygınlaştırılması }\end{array}$ \\
\hline
\end{tabular}

Şekil 3 Karayolu Trafik Güvenliği Alanındaki Hizmetlerin Küresel Kamusal Malların Toplam Sunum Teknolojileri Kriteri Açısından Sınıflanması

Şekil-3'e göre, Karayolu Trafik Güvenliği'ni artırıcı hizmetler ulusal, bölgesel ya da küresel ölçekte sunulabilmektedir. Bu hizmetlerin sunumunda sunumu yapan her bir aktörün hizmetinin toplamı; ya da en iyi sonucu veren sunucunun hizmeti baz alınabileceği gibi en zayıf halka tekniği gereği, sunumu yapan en zayıf aktörün sunum şekli de elde edilen faydanın tasnifi için kullanılabilmektedir.

Örneğin tüm yerel aktörlerin şehir içi ulaşımı ve trafik tıkanıklarını çözmeye yönelik hizmetlerinin toplamı ele alınacak olursa ulusal bazda toplama tekniğine uygun bir değerlendirme yapılmış olacaktır. Trafik güvenliği alanında toplama tekniği açısından fayda sağlamaya yönelik bölgesel bir örnek olarak da ulaştırma modları arasında uyumluluk çalışmaları gösterilebilir. Entegrasyonun sağlanmış olduğu çok modlu bir ulaştırma alt yapısı oluşturulması, güvenli ulaşım açısından dağılımın daha sağlıklı yapıldığı bir sektörel ağırlık oluşturacak ek dişsal maliyetleri azaltacaktır. Buna rağmen hala dışsal maliyetler söz konusu olduğundan toplama tekniği açısından küresel bazda yol güvenliği hizmetlerinin sunumu da gerekmektedir. 'Vergi ve Regülasyonlar' ile bu alanda ulus devletlerin eksik biraktığı düzenlemeler yapıldığında sözü edilen dışsal maliyetler açısından düzelme sağlanacaktır.

ILO ve AB'nin karayollarında çalışan personele yönelik çalışma ve dinlenme sürelerinin ülkelerce yaygın olarak uygulanmaya başlaması ile karayollarında daha güvenli seyahat edileceği varsayımında olduğu gibi, her bir ülkenin gerekli mevzuat düzenlemelerini yaptığında küresel boyutta faydanın yaygınlaşması söz konusu ise toplama tekniği gereği sunum yapılmalıdır. $\mathrm{Bu}$ sayede ülkelerden birinde ortaya çıkan fayda diğeri tarafindan olumsuz etkilenmeyecektir. 
Trafik güvenliğini artırmaya yönelik hizmetler en iyi vuruş tekniği açısından incelenecek olursa; yerel bazda en dikkat çekici örnek yol ve işaret standartlarında sağlanması mümkün iyileştirmelerdir. Yine trafik eğitimine yönelik eğitim faaliyetleri de aynı başlı̆̆ı örneklemektedir. Aynı amaçla bölgesel bazda yapılacak hizmetler için ise TRACECA koridoru ya da TEN-T Ulaşım Ağları Projesi örnek teşkil etmektedir. Bu tarz projeler ile ulaşım alanında bölgesel güvenlik ve entegrasyona katkı sağlanmaktadır. Yine de dışsal maliyetlerin düşürülmesi açısından küresel ölçekte hizmetlere ihtiyaç vardır. Bu konuda BM teşkilatı DSÖ ve ASIRT gibi kurumları aracılığıyla, OECD ise IRTAD'ın faaliyetleri ile hizmet sunmaktadır.

Konuya örnek olması açısından, Finlandiya'nın dünya emisyon salınımı açısından \% 0,3'lük yer işgal etmesine rağmen çevre tabanlı vergiler koyduğu düşünülürse, çevre alanında alınacak önlemler söz konusu olduğunda en iyi vuruş tekniği gereği sunum yapılması öne çıkartılmalıdır. Böylelikle ülkelerin sorumluluklarını yerine getirmesi yüzdesi yükseltilerek daha etkin bir yol güvenliği sağlanması söz konusu olabilecektir.

En zayıf halka tekniği açısından bir değerlendirme yapılacak olduğunda, yerel ve ulusal ölçekte hizmet sunumunda başarılı olunamadığında, maddi kayıplar ve işgücü kayıpları yaşanması örnektir. Aynı şekilde motorlu taşıt sayısının çok az olduğu Afrika kıtasında, yol kazaları sebebiyle gerçekleşen ölüm oranlarının yüksek olması sunum açısından en zayıf halka tekniği ile yapılacak değerlendirmeleri ön plana çıkartmaktadır. Zira motorlu taşıtların \% 1'ine sahip olan Afrika kıtası kazalara bağlı kişi ölümlerinde yüz bin kişide 26,6 gibi dünya genelindeki en yüksek düzeye sahiptir. Bu durumda korunmasız yol kullanıcılarına yönelik küresel tedbirler geliştirilirken, en zayıf halka tekniği gereği sunum yapılması öne çıkartılmalıdır. Bu sayede elde edilecek küresel fayda en yüksek düzeye çıkartılmış, küresel anlamda dışsallıkların azaltılmasına olumlu katkı sağlanmış olacaktır.

Bütün bunlara ilave olarak söylenecek önemli bir başka konu da; araç standartları ile yol standartlarının geliştirilmesi ve bilgi paylaşımı gibi konularda küresel ölçekte yapılacak sunumların güvenlik alanındaki etkinliklerinin artırılması için ise ağırlıklı ortalama tekniği gereği sunum yapılmalıdır. Böylelikle teknolojisi daha geride olan ülkeler daha ileride olan ülkelerin toplam sunumundan olumlu etkilenecek ve aradaki fark açılmadığı için toplamda elde edilen fayda daha yaygın olacaktır.

\subsection{Küresel Kamusal Malların Diğer Özelliklerine Göre Yapılan Sınıflama Açısından Karayolu Trafik Güvenliği Hizmetleri}

Küresel Kamusal Mallar pek çok farklı açıdan sınıflanabildiği gibi, yol güvenliğini artırıcı hizmetlerin de çok farklı bakış açıları ve çok disiplinli bir yaklaşımla ele alınması faydalı bir yaklaşımdır. Bu konudaki örnekler aşağıda Şekil-4 ve Şekil-5'te ortaya konmuştur.

Karayolu Trafik Güvenliği alanındaki hizmetlerin Morrissey ve Hewitt'in (2002) Sektörel bazda yapılan Küresel Kamusal Mal sınıflaması açısından incelenmesi sonucu ortaya çıkacak örnekler aşağıdaki Şekil-4'de yer almaktadır. 


\begin{tabular}{|c|c|c|c|c|}
\hline \multicolumn{2}{|c|}{ Kamu Malı } & \multirow{2}{*}{$\begin{array}{c}\text { Çekirdek Küresel Kamusal } \\
\text { Mallar }\end{array}$} & \multicolumn{2}{|c|}{$\begin{array}{l}\text { Tamamlayıcı } \\
\text { Küresel Kamusal Mallar }\end{array}$} \\
\hline & ektör & & Üretim & Tüketim \\
\hline 己े. & Küresel & $\begin{array}{l}\text { Egsoz Gaz1 Emisyonunun } \\
\text { Azalt1lması }\end{array}$ & $\begin{array}{c}\text { AR-GE Faaliyetleri } \\
\text { Vergi ve Regülasyonlar }\end{array}$ & $\begin{array}{l}\text { Küresel Vergileme } \\
\text { Eğitim Faaliyetleri } \\
\text { ve Farkındalık yaratma } \\
\text { çalışmaları }\end{array}$ \\
\hline 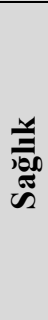 & Küresel & $\begin{array}{l}\text { Yetişmiş Sağlık ve } \\
\text { İlkyardım Personeli; } \\
\text { Hastaneler }\end{array}$ & $\begin{array}{c}\text { DSÖ } \\
\text { Koordinatörlüğündeki } \\
\text { Faaliyetler (Emniyet } \\
\text { Kemeri, Kask, Çocuk } \\
\text { Koltuğu vb.) } \\
\text { Yol ve Araç Standartları } \\
\text { ile İlgili Regülasyonlar }\end{array}$ & $\begin{array}{c}30 \text { Gün Takip Sisteminin } \\
\text { Yaygınlaştırılması, } \\
\text { Kızılhaç, Kızılay, } \\
\text { Yeşilay Faaliyetleri } \\
\\
\text { Hastaneler, Okullar, } \\
\text { Medya Kuruluşları }\end{array}$ \\
\hline$\frac{50}{20}$ & Küresel & $\begin{array}{l}\text { Veri Tabanları } \\
\text { Oluşturulması } \\
\text { (OECD/IRTAD } \\
\text { Faaliyetleri) } \\
\\
\text { Eğitim Faaliyetleri, } \\
\text { Mesleki Eğitim }\end{array}$ & $\begin{array}{l}\text { Formel ve İnformel } \\
\text { Eğitimin } \\
\text { Yaygınlaştırılması }\end{array}$ & $\begin{array}{l}\text { Enstitüler, Üniversiteler, } \\
\text { Organizasyonlar, } \\
\text { Gönüllü Kuruluşlar } \\
\text { Okullar, Medya (Türkiye } \\
\text { için RTÜK) }\end{array}$ \\
\hline 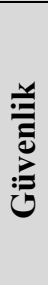 & Küresel & $\begin{array}{c}\text { TRACECA Koridoru; } \\
\text { TEN-T Ulaşım ağları } \\
\text { projeleri } \\
\text { Tescil İşlemleri ve Sicil } \\
\text { Takip Sistemi, Akıllı } \\
\text { Ulaşım Sistemleri }\end{array}$ & $\begin{array}{l}\text { Ortak Mevzuat } \\
\text { Düzenlemeleri, } \\
\text { Ehliyet Sistemi } \\
\text { Ceza } \\
\text { Ve } \\
\text { Denetimler }\end{array}$ & $\begin{array}{l}\text { Fakirliğin Azaltılması, } \\
\text { Kalkınmışlık Farklarının } \\
\text { Ortadan Kalkması }\end{array}$ \\
\hline 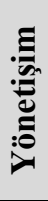 & Küresel & $\begin{array}{c}\text { DB, BM, OECD, AB, ILO } \\
\text { vb. Örgütlerin Yol } \\
\text { Güvenliği Faaliyetleri } \\
\text { Mevzuat Düzenlemeleri }\end{array}$ & $\begin{array}{l}\text { Risk Gruplarının } \\
\text { Belirlenmesi } \\
\text { Ulaştırma Planlaması } \\
\text { (Kalkınma Planları) }\end{array}$ & Gelir Artırıcı Etkiler \\
\hline
\end{tabular}

\section{Şekil 4 Küresel Kamusal Malların Sektörel Bazda Sınıflanması ve Karayolu Trafik Güvenliği Hizmetleri}

Şekil-4'de küresel kamusal mallar Dünya Bankası'nın da öngördüğü gibi çekirdek ve tamamlayıcı mallar olmak üzere sınıflanmıştır. Bu sınıflama sistematiği dikkate alındığında bir küresel kamusal mal sunumu söz konusu olduğunda, bundan elde edilecek fayda ya da kaçınılacak zararın büyüklüğü, sadece sunum miktarı ile değil, sunumu yapılan mal ya da hizmete ulaşılabilirlik ile de açık bir ilgiye sahiptir.

Kaul vd. (1999) çekirdek malları uluslar arası çaba ile ortaya konan bir somut mal ya da politika olarak tanımlarken; tamamlayıcı malları bu politikalara ya da mallara ulaşmanın bir destekleyicisi olarak görmektedirler (Kaul, Grunberg, \& Stern, 1999a: 13).

Bir başka küresel kamusal mal sınıflaması şekli de faydanın türünü göre yapılan sınıflama şeklidir. Aşağıda yer alan Şekil-5'de Morrissey ve Hewitt'in (2002) fayda türüne göre 
yaptığı Küresel Kamusal Mal sınıflaması açısından trafik güvenliği alanında sunulan hizmetlerin değerlendirilmesi yer bulmaktadır.

\begin{tabular}{|c|c|c|c|}
\hline & \multicolumn{3}{|c|}{ Faydanın Türü } \\
\hline Fayda Alanı & Risk Azaltımı & Kapasite Artırımı & Doğrudan Fayda \\
\hline Küresel & $\begin{array}{l}\text { Yol Ölümleri ve } \\
\text { Sakatlanmalarının } \\
\text { Önlenmesi } \\
\text { Çevresel Dışsallıkların } \\
\text { Azaltılması } \\
\text { Mültecilik Sorununun } \\
\text { Azaltılması }\end{array}$ & $\begin{array}{l}\text { İşgücü Kaybının } \\
\text { Önlenmesi } \\
\text { Barış ve Güvenlik } \\
\text { Küresel Bilgi Paylaşımı ve } \\
\text { Yönetişim }\end{array}$ & $\begin{array}{l}\text { Fakirliğin } \\
\text { Azalması } \\
\text { Finansal } \\
\text { İstikrar }\end{array}$ \\
\hline Bölgesel & $\begin{array}{l}\text { Çatışmaların Azaltılması } \\
\text { Ekonomik ve Sosyal } \\
\text { Kayıpların Azaltılması }\end{array}$ & $\begin{array}{l}\text { Piyasa Rekabetinde } \\
\text { Etkinlik } \\
\text { Çalışma Çağındaki } \\
\text { Nüfusun Verimliliği }\end{array}$ & $\begin{array}{l}\text { Bölgesel Gelir } \\
\text { Dağılımı } \\
\text { Eşitsizliğinin } \\
\text { Azalması } \\
\text { Kalkınma ve } \\
\text { Büyüme }\end{array}$ \\
\hline
\end{tabular}

Şekil 5 Faydanın Türüne Göre Yapılan Küresel Kamusal Mal Sınıflaması ve Karayolu Trafik Güvenliğini Artırıcı Hizmetler İlişkisi

Şekil-5 yol güvenliğini artırıcı faaliyetler sonucu ortaya çıkan fayda ya da kaçınılan zarar esas alınarak yapılan KKM sınıflamasının, yol güvenliğini artırıcı hizmetlere uyarlanmasını içermektedir. Şekil-5'e göre yol güvenliğini artırıcı bazı hizmetler, ortaya çıkacak dışsal maliyet risklerini azaltırken, bazı faaliyetler dolaylı ya da doğrudan faydaları içermektedir.

Risk Azaltımı başlığı açısından incelersek; yol güvenliği arttığında ekonomik ve sosyal kayıpların azalması, bölgesel refahı ve ekonomik kalkınmayı hızlandıracaktır. Bu durumda çatışmaların azalması ve dolayısıyla bölgesel göçün önüne geçilmesi mümkün olacaktır. Günümüz dünyasında mültecilik sorunu çözümü için küresel ölçekte çaba harcanan bir sorun halini almıştır.

Kapasite artırımı başlığı açısından incelersek; yol güvenliği arttığında işgücü kaybı açısından ve çalışma çağındaki nüfusun verimliliği açısından olumlu sonuçlar elde edileceği görülmektedir. Daha önce yol çarpışmaları nedeniyle risk altında olan gruplar ele alınırken çalışma çağındaki nüfus ve bunun için de erkek nüfus açısından kazaların daha yıkıcı sonuçları olduğunu anlatmıştık. $\mathrm{Bu}$ anlamda yol güvenliği hizmetlerinin geliştirilmesiyle, çalışma çağındaki nüfusun verimliliği açısından sağlanacak bir kapasite artırımının piyasa rekabeti açısından da olumlu sonuçlar doğurması kaçınılmazdır. Yol güvenliği hizmetlerin artırılması ile veri paylaşımı açısından da kapasite artışı sağlanacaktır.

Doğrudan fayda başlığı açısından incelersek; hizmet sektörü içinde yer alan ve diğer tüm sektörler ile doğrudan ilişkisi bulunan ulaştırma sektörünün daha güvenli hale getirilmesi, yukarıda sayılan işgücü ve piyasa rekabeti şartlarına katkılarıyla, kalkınma ve finansal 
istikrar alanlarına da olumlu yönde etki edecektir. Vasıflı işgücünün korunması, ülkelerin rekabetçi piyasa şartlarında geri düşmesinin önlenmesi ve ekonomik kalkınma açısından da önem arz etmektedir.

Görüldüğü üzere tüm dünyadaki yol güvenliği hizmet sunumları dikkate alındığında, küresel kamusal mallar sistematiği ile ilişki derecesi açısından kuvvetli bir etkileşim söz konusudur. Yol güvenliğini artırabilmek ve bir kamusal kötü haline gelen karayolu çarpışmalarının olumsuz sonuçlarını ortadan kaldırabilmek için küresel ölçekte harcanan çabaların daha sistemli ve düzenli hale getirilmesi, tüm insanlık için faydalı olacaktır.

\section{Sonuç}

Ülkelerin Ulaştırma Sektöründeki organizasyon kabiliyeti ile kalkınmışlık düzeyleri doğrudan ilgilidir. Sanayileşme ve üretim, pazara ulaşmayı zorunlu kılan faktörlerdir. Toplumsal gelişme ve politik karar alma sürecindeki başarı için ulaşım planlaması faaliyetlerinin yapılıp, uygulanması zorunluluktur. Ülkeler bu yüzden ulaşım ve lojistik sektörlerine, ulusal ve bölgesel kalkınma planlarında yer vermektedir. Dünyada ulaşım modları arasında karayolu ulaşımı alt sektörü dengesiz bir biçimde öne çıkmaktadır. Karayollarının aşırı yoğunluğu ve ulaşım modlarında entegrasyonun sağlanamaması sebebiyle oluşan dışsallıklar dev küresel sorunların sebebidir. Dışsallıklar nedeniyle sorunun çözümünde kamusallık boyutu göz ardı edilmemelidir.

BM Genel Kurul kararıyla Trafik Güvenliği alanındaki faaliyetlerde koordinatörlük görevini DSÖ yürütmektedir. Bu durum olumlu sonuçlar doğursa da yerel aktörlere yaptırımının olmaması sebebiyle yetersizdir. DSÖ verilerine göre karayolu trafik kazaları nedeniyle dünya genelinde her yıl yaklaşık 1,25 milyon insan hayatını kaybetmekte ve 50 milyona yakın insan kalıcı sakatlık sorunları ile karşılaşmaktadır. Günümüzde tüm ölümler içinde sekizinci sırada yer alan trafik kazası sebebiyle ölümler, 2030 yılına kadar beşinci sıraya çıkacaktır. Bu yüzden DSÖ Karayolu trafik ölümlerini bir 'Kamu Sağğı̆̆ Problemi' olarak tanımlamaktadır. Hastalıklarla mücadele açısından küresel boyutta faaliyetler sürmekte ve sağlık alanındaki hizmetler küresel kamusal mallar arasında genel kabul görmektedir. Karayolu çarpışmaları sebebiyle oluşan kayıpların da bu nedenle bir kamusal kötü olarak kabul edilmesi ve bu alanda etkin mücadele gerekmektedir.

Trafik kazaları sebebiyle ülkeler her yıl GSYİH'larının yaklaşık \% 1,5-2'si arasında bir ortalama kayıp vermektedir. 2015 yılı Kasım ayında Brezilya'da yapılan İkinci Küresel Yüksek Düzey Yol Güvenliği Konferansı'nda yol kazaları sebebiyle oluşan küresel kaybın yıllık yaklaşık maliyetinin 1 trilyon 850 milyar dolar olduğu ifade edilmiştir. Karayolu ulaşımının güvenliği için katlanılan bireysel maliyetlerden çok daha fazlası gizli kalmış kamusal maliyetler olarak karşımıza çıkmaktadır. Karayolları ulaşım dışsallıkları sadece yol kullanıcılarını değil ekonomik ve sosyal açıdan tüm insanlığı ve hatta gelecek nesilleri de etkilemektedir. Bu etkiler açısından dişlanamazlık söz konusudur. Nesiller arası etkiler de göz önüne alındığından Karayolu Trafik Güvenliği'ni artırıcı hizmetler Küresel Kamusal Mallar arasında sayılmalıdır.

Küresel sorunlar sadece yerel çaba ile çözümlenemeyecek kadar büyük finansal altyapı gerektirmektedir. $\mathrm{Bu}$ sebeple çözüme de ancak küresel ölçekli faaliyetler ile ulaşılması mümkündür. Önlenebilir nitelikteki trafik kazalarının ortadan kaldırılması için mevzuat yoluyla yapılacak düzenlemelerin dünya genelinde yaygınlaştırılması gerekmektedir. Bunun için yerel hükümetlerin istekli olması yanında bilgi edinim ve paylaşımının da önemi tartışmasızdır. Karayolu Trafik Güvenliği alanında dünya genelinde yapılan pek çok çalışma 
olsa da, sadece bu alanla ilgili çalışma yürüten birim yok denecek kadar azdır. Genellikle farklı alanlarda faaliyet yürütmek için kurulmuş birimler yol güvenliğini de artırma gayreti içindedirler. Trafik güvenliği alanı açısından ülkelerin yerleşik ulusal mevzuatları genellikle yetersizlikler içermektedir. Ulus üstü oluşumlar için ise bir dağınıklık ve yetki belirsizliği gözlenmektedir. Daha etkin mücadele için toparlayıcı ve yetki tanımı daha sağlıklı yapılmış olan ulusal ve ulus üstü çabalara ihtiyaç vardır. Küresel boyutta elde edilen faydalar düşünüldüğünde, yol güvenliğinin arttırılmasıyla ilgili eylemler (kamusal kötülerden korunmak) kamusal faydaların oluşmasını sağlayacaktır. 


\section{KAYNAKÇA}

AKDEMIR, A., \& ŞAHIN, M. (2006). Küresel Kamusal Malların Üretim ve Yönetim Dinamikleri Bağlamında Sınıflandırılması. Maliye Dergisi (150), 1- 24.

ALKAN, A., KARACA, E., \& ALADAĞ, Z. (2011, Haziran 23-24). Otomotiv Sektöründe Emisyon Tarihlerine Bağlı Aşamalı Karar Analizi. Eylül 22, 2015 tarihinde iticu.edu.tr:

acikerisim.iticu.edu.tr:8080/xmlui/bitstream/handle/11467/562/M00388.pdf?sequenc $\mathrm{e}=1 \&$ isAllowed $=\mathrm{y}$ adresinden alınd 1

BRASILIA DEKLARASYONU, (2015, Kasım 18-19). Kasım 28, 2015 tarihinde Dünya Sağlık Örgütü Web Portal: http://www.who.int/violence_injury_prevention/road_traffic/Brasilia_Declaration/en / adresinden alındı

ÇELEBİ, A. K., \& YALÇIN, A. Z. (2008). Kamusal Mallar Teorisinin Değişimi: Bölgesel Kamusal Mallar. Yönetim ve Ekonomi , 15 (2), 1-18.

DURNA, T. (2015, Ekim 26). Karayolu Güvenliğinde Küresel Durum. Kasım 01， 2015 tarihinde Global Politika ve Strateji: globalpse.org/karayolu-guvenliginde-kuresel durum/ adresinden alınd 1

EMIROĞLU, H. (2006). Soğuk Savaş Sonrası Birleşmiş Milletler: İşlevi-Sorunları. C. $U$. İktisadi ve İdari Bilimler Dergisi , 7 (2), 59-81.

FREUND, P., \& MARTIN, G. (1996). Otomobilin Ekolojisi. (G. Koca, Çev.) İstanbul, Türkiye: Ayrıntı Yayınları. (Eserin orijinali 1996'da yayımlandı).

KAPAR, R. (2007, Ocak-Şubat-Mart). Uygun İş Açı̆̆ı: İnsana Yaraşmayan Ｉ̇şler. Türk Tabipleri Birliği Mesleki Sağllk ve Güvenlik Dergisi , 2-10.

KAUL, I. (2005). Global Public Goods: A Key To Achieving The Millennium Development Goals. Prepared For The Third Forum On Human Development: Cultural Identity, Democracy And Global Equity. Paris.

KAUL, I. (1999). Public Goods: Taking the Concept to the 21st Century. Kasim 24, 2014 tarihinde York University Web Portal: www.yorku.ca/drache/talks/pdf/apd_kaulfin.pdf adresinden alındı

KAUL, I., \& CONCEIÇAO, P. (2006b). The Changes Under Way: Financing Global Challenges Through International Cooperation Behind And Beyond Borders. I. Kaul, \& P. Conceiçao (Ed.), Overview The New Public Finans; Responding To Global Challenges (s. 26-68). New York, USA: Oxford University Press.

KAUL, I., \& CONCEIÇAO, P. (2006a). Why Revisit Public Finance Today? What The Book Is About. I. Kaul, \& P. Conceiçao (Ed.), Overview The New Public Finans; Responding To Global Challenges (s. 1-25). New York, USA: Oxford University Press.

KAUL, I., GRUNBERG, I., \& STERN, M. A. (1999b). Concepts, Policies and Strategies. I. Kaul, I. Grunberg, M. A. Stern, I. Kaul, I. Grunberg, \& M. A. Stern (Ed.), Global Public Goods. International Cooperation In The 21st Century (s. 450-507). New York, USA: Oxford University.

KAULl, I., GRUNBERG, I., \& STERN, M. A. (1999a). Defining Global Public Goods. I. Kaul, I. Grunberg, M. A. Stern, I. Kaul, I. Grunberg, \& M. A. Stern (Ed.), Global Public Goods. International Cooperation In The 21st Century (s. 2-20). New York, USA: Oxford University Press.

KIRMANOĞLU, H., YILMAZ, B. E., \& SUSAM, N. (2006). Maliye Teorisinin Çıkmazı: Küresel Kamusal Mallar (Kalkınma Yardımları İçinde Küresel Kamusal Malların Finansman1). Maliye Dergisi (150), 25-52. 
KUYZU, G., \& TEKIN, S. (2013, Aralık). Batı Karadeniz Kalkınma Ajansı Ulaşım ve Lojistik Master Planı. Türkiye: TOBB Ekonomi ve Teknoloji Üniversitesi.

LORASOKKAY, M. A., ÇELIKK, O. N., \& ATASAĞUN, N. (2013). Trafik Kazaları ve KOP Değerlendirmesi. Ulusal KOP Bölgesel Kalkınma Sempozyumu, (s. 1-8). Konya.

OICA, (2015), Kasım 1, 2015 tarihinde International Organization of Motor Vehicle Manufacturers: http://www.oica.net/category/production-statistics/2014-statistics/ adresinden alınd 1

RAO, J. M. (1999). Equity In A Global Public Goods Framework. I. Kaul, I. Grunberg, \& M. A. Stern (Ed.), Global Public Goods. International Cooperation In The 21st Century (s. 68-87). New York, USA: Oxford University Press.

RESMİ GAZETE. (1983, Ekim 18). 2918 Sayll Karayollarl Trafik Kanunu (18195) . Türkiye: T.C. Resmi Gazete.

SANDLER, T. (1999). Intergenerational Public Goods, Strategies, Efficiency and Institutions. I. Kaul, I. Grunberg, \& M. A. Stern (Ed.), Global Public Goods. International Cooperation In The 21st Century (s. 20-51). NewYork, USA: Oxford University Press.

SEMIZ, E., ÇELIK, Y., \& VURSAVAŞ, F. (2012, Ağustos 15). Uluslar arası Kuruluşlar ve Karayolu Trafik Güvenliği. Türkiye Belediyeler Birliği Iller ve Belediyeler Dergisi, $55-63$.

TISPOL. (2015, May1s 20). May1s 21, 2015 tarihinde European Traffic Police Network: https://www.tispol.org/about/european-commission/european-commission adresinden alınd 1

WEGMAN, F. (1996). Karayolu Trafik Kazaları: Başarıyla Üstesinden Gelinebilecek Dünya Çapında Bir Problem! Başarıla Üstesinden Gelinebilecek Dünya Çapında Bir Problem, 1-52. (T. Kiper, Çev.) Türkiye: PIARC Karayolu Güvenliği Komitesi. (Eserin orijinali 1996'da yayımlanmıştır)

WHO. (2013). Global Status Report On Road Safety 2013. WHO.

WHO. (2015a). Dünya Sağllk Örgütü Resmi Web Sitesi. Şubat 9, 2015 tarihinde WHO: http://www.who.int/gho/road_safety/mortality/number_text/en/adresinden alınd1

WHO. (2015b). Global Status Report On Road Safety 2015. WHO. 